\title{
Conclusion: The Contribution of a Living Heritage Approach to the Discipline of Conservation
}

\begin{abstract}
A living heritage approach: challenging assumptions in conservation
A living heritage approach tends to radically redefine the existing concept of heritage and the principles of heritage conservation by challenging, for the first time in the history of conservation, very strong assumptions established over time in the field, which were developed along with a material-based approach and were maintained by a values-based approach (see Part 1; see also Poulios 2014). More specifically, according to a living heritage approach, first, the power in the conservation process is longer in the hands of the conservation professionals, but passes on to the communities. Second, emphasis is no longer be on the preservation of the (tangible) material but on the maintenance of the (intangible) connection of communities with heritage, even if the material might be harmed. Third, heritage is not considered a monument of the past that has to be protected from the present community, for the sake of the future generations; heritage is now seen and protected as an inseparable part of the life of the present community. Thus, past and present-future are not separated (discontinuity), but unified into an ongoing present (continuity). Therefore, a living heritage approach attempts to mark the shift in heritage conservation from monuments to people, from the tangible fabric to intangible connections with heritage, and from discontinuity to continuity.
\end{abstract}

\section{A living heritage approach in relation to a material-based and a values-based approach}

These three approaches to conservation (table 1) reflect different strategies. From the perspective of strategy, a living heritage approach, by radically redefining the existing concept of heritage and the practice of heritage conservation, can be seen as an example of 'Strategic Innovation' (introducing a new 'who'-'what'-'how': see Poulios 2014). Specifically, a living heritage approach proposes a different concept of heritage and conservation, based on the community's original connection with heritage / continuity and with an emphasis on the intangible elements rather than the tangible ones (a new 'what'); it points at a different community group as responsible for the definition and protection of heritage, i.e. the core community (a new 'who'); and it proposes 


\begin{tabular}{|c|c|c|c|}
\hline & material-based approach & values-based approach & living heritage approach \\
\hline \multirow{3}{*}{$\begin{array}{l}\text { the meaning of herit- } \\
\text { age and the aim of } \\
\text { conservation }\end{array}$} & fabric & values & $\begin{array}{l}\text { living heritage / } \\
\text { continuity }\end{array}$ \\
\hline & & $\begin{array}{l}\text { tangible and intangible } \\
\text { values, mostly separated } \\
\text { from each other }\end{array}$ & $\begin{array}{l}\text { tangible and intangible } \\
\text { heritage expressions, } \\
\text { seen as an inseparable } \\
\text { unity }\end{array}$ \\
\hline & & $\begin{array}{l}\text { all values equal, but } \\
\text { emphasis on the tangible } \\
\text { ones (fabric) }\end{array}$ & $\begin{array}{l}\text { not equal heritage } \\
\text { expressions; emphasis on } \\
\text { the intangible ones }\end{array}$ \\
\hline \multirow[t]{2}{*}{$\begin{array}{l}\text { the community group } \\
\text { responsible for herit- } \\
\text { age definition and } \\
\text { protection }\end{array}$} & $\begin{array}{l}\text { heritage authori- } \\
\text { ties (conservation } \\
\text { professionals) }\end{array}$ & stakeholder groups & $\begin{array}{l}\text { core community (that } \\
\text { retains its original con- } \\
\text { nection with heritage/ } \\
\text { continuity) }\end{array}$ \\
\hline & & $\begin{array}{l}\text { all groups equal, but } \\
\text { emphasis on those asso- } \\
\text { ciated with the fabric }\end{array}$ & $\begin{array}{l}\text { not equal groups; prior- } \\
\text { ity to the particular com- } \\
\text { munity (continuity) }\end{array}$ \\
\hline \multirow[t]{7}{*}{$\begin{array}{l}\text { the way heritage is pro- } \\
\text { tected by the relevant } \\
\text { community group }\end{array}$} & $\begin{array}{l}\text { power in the conser- } \\
\text { vation profession- } \\
\text { als- no community } \\
\text { involvement }\end{array}$ & $\begin{array}{l}\text { community involve- } \\
\text { ment under the supervi- } \\
\text { sion of conservation } \\
\text { professionals }\end{array}$ & $\begin{array}{l}\text { community empower- } \\
\text { ment, with the sup- } \\
\text { port of conservation } \\
\text { professionals }\end{array}$ \\
\hline & a top-down approach & $\begin{array}{l}\text { tries to be bottom-up } \\
\text { but often ends up being } \\
\text { top-down }\end{array}$ & a bottom-up approach \\
\hline & $\begin{array}{l}\text { dependent on legal } \\
\text { frameworks of } \\
\text { protection }\end{array}$ & $\begin{array}{l}\text { dependent on legal } \\
\text { frameworks of } \\
\text { protection }\end{array}$ & $\begin{array}{l}\text { dependent on commu- } \\
\text { nity empowerment }\end{array}$ \\
\hline & $\begin{array}{l}\text { primary aim of } \\
\text { conservation: } \\
\text { preservation of heritage }\end{array}$ & $\begin{array}{l}\text { primary aim of } \\
\text { conservation: } \\
\text { preservation of heritage }\end{array}$ & $\begin{array}{l}\text { primary aim of conser- } \\
\text { vation: maintenance } \\
\text { and enhancement of } \\
\text { continuity (preserva- } \\
\text { tion of heritage within } \\
\text { the maintenance of } \\
\text { continuity) }\end{array}$ \\
\hline & $\begin{array}{l}\text { heritage significance } \\
\text { based on 'expert' values }\end{array}$ & $\begin{array}{l}\text { heritage significance } \\
\text { based on 'expert' values } \\
\text { and including stake- } \\
\text { holder values }\end{array}$ & $\begin{array}{l}\text { heritage significance } \\
\text { based on core commu- } \\
\text { nity values and includ- } \\
\text { ing 'expert' values and } \\
\text { broader community } \\
\text { (stakeholder) values }\end{array}$ \\
\hline & $\begin{array}{l}\text { treating fabric as a non- } \\
\text { 'renewable' resource }\end{array}$ & $\begin{array}{l}\text { treating fabric as a non- } \\
\text { 'renewable' resource }\end{array}$ & $\begin{array}{l}\text { treating fabric as a } \\
\text { 'renewable' resource }\end{array}$ \\
\hline & $\begin{array}{l}\text { only minimal interven- } \\
\text { tions to heritage, with } \\
\text { respect to the material } \\
\text { structure }\end{array}$ & $\begin{array}{l}\text { mostly minimal inter- } \\
\text { ventions to heritage, } \\
\text { with respect to the mate- } \\
\text { rial structure }\end{array}$ & $\begin{array}{l}\text { even major interventions } \\
\text { to heritage, with little } \\
\text { respect to the material } \\
\text { structure }\end{array}$ \\
\hline
\end{tabular}


(Table continued from previous page)

\begin{tabular}{|l|l|l|l|}
\hline & $\begin{array}{l}\text { development potentials } \\
\text { on the basis of conser- } \\
\text { vation professionals' } \\
\text { interests }\end{array}$ & $\begin{array}{l}\text { development potentials } \\
\text { on the basis of stake- } \\
\text { holder groups' concerns, } \\
\text { but under conservation } \\
\text { professionals' control }\end{array}$ & $\begin{array}{l}\text { development potentials } \\
\text { on the basis of core } \\
\text { community's concerns } \\
\text { and connection with } \\
\text { heritage, with conser- } \\
\text { vation professionals' } \\
\text { support }\end{array}$ \\
\hline$\underline{\text { the philosophy of }}$ & $\begin{array}{l}\text { conservation } \\
\text { expert-driven approach: } \\
\text { power in the conserva- } \\
\text { tion professionals- no } \\
\text { community involvement }\end{array}$ & $\begin{array}{l}\text { expert-driven approach: } \\
\text { community is involved, } \\
\text { but power is in the con- } \\
\text { servation professionals }\end{array}$ & $\begin{array}{l}\text { community-driven } \\
\text { approach: power is in } \\
\text { the community, with the } \\
\text { support of conservation } \\
\text { professionals }\end{array}$ \\
\hline & $\begin{array}{l}\text { discontinuity: preserva- } \\
\text { tion of heritage consid- } \\
\text { ered to belong to the } \\
\text { past, from the present } \\
\text { community, for the sake } \\
\text { of the future }\end{array}$ & $\begin{array}{l}\text { discontinuity: preserva- } \\
\text { tion of heritage consid- } \\
\text { ered to belong to the } \\
\text { past, from the present } \\
\text { community, for the sake } \\
\text { of the future }\end{array}$ & $\begin{array}{l}\text { continuity: preservation } \\
\text { of heritage as part of the } \\
\text { present community, by } \\
\text { the present community, } \\
\text { for the sake of the pre- } \\
\text { sent community }\end{array}$ \\
\hline
\end{tabular}

Table 1: A living heritage approach in relation to a material-based and a values-based approach (in detail) (see Poulios 2014).

a different way of heritage protection through community empowerment and through prioritising traditional care over modern scientific-based conservation (a new 'how').

Despite the differences between a living heritage approach and a values-based approach, there are cases in which the management of a site would require the combination of (elements of) both approaches, depending on the specific conditions at site level and more specifically on the way continuity has evolved over the course of time to present (see above). Such a combined approach (figure 54; see Poulios 2010c) has been suggested for the management of the living Pantanassa Monastery within the necropolis of Mystras (where the monastic community has remained to present, yet adjusts its life on the basis of the regulations defined by the State, with severe restrictions on its spatial arrangement and its opening hours: see above, figures 49 and 50). However, the existence of such cases does not mean that a living heritage approach is the same with a valuesbased approach.

\section{A different way of looking at authenticity}

The current theoretical framework and practice of heritage conservation, in the context of a material-based and also a values-based based approach (based on discontinuity between the sites, considered to belong to the past, and the people of the present), and a living heritage approach (based on functional continuity) tend to see and safeguard authenticity in different and even conflicting ways (see also Poulios 2010). According to a material-based and a values-based approach, authenticity is considered to lie in the past and to be associated mostly with the (tangible) fabric of a site. According to a living heritage approach, authenticity is in the present, and is associated mostly with the communities' (intangible) association with a site. A material-based and a valuesbased approach concentrates on the preservation of a site, as an obligation to the past generations and also in the name of the present public and the future generations. A living heritage approach 


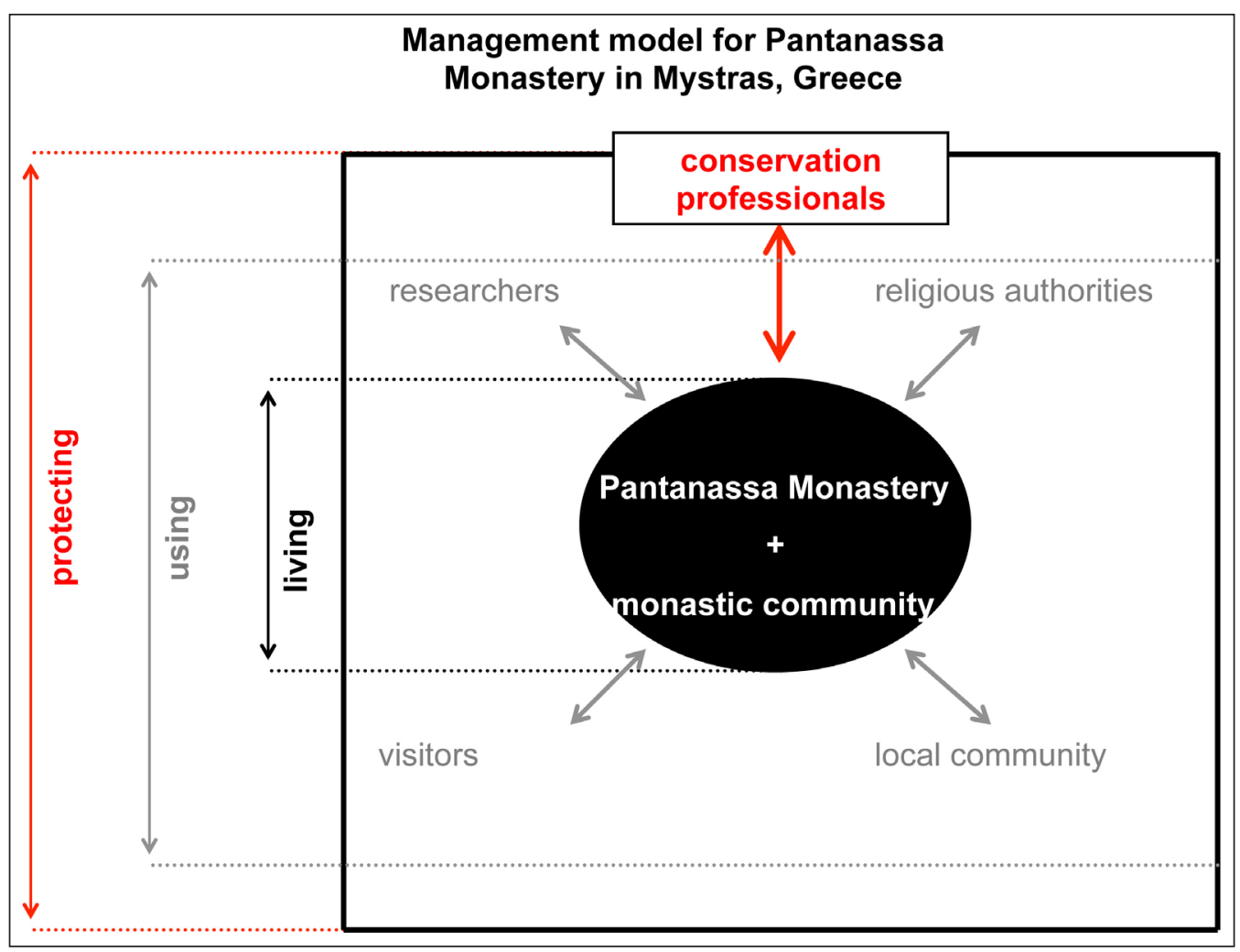

Figure 54: The approach that has been suggested for the management of the Pantanassa Monastery of Mystras in Greece (Poulios 2010c) is a combination of a living heritage approach (figure 52) and a values-based approach (figure 4). The monastic community is considered an inseparable part of the Monastery and is responsible for the issues of the (monastic) function of the Monastery - and is thus the 'core community', while the other communities that participate in the operation of the Monastery (the figure mentions some indicative examples of such communities) consist the 'broader community' (i.e. on the basis of a living heritage approach). Yet, the conservation professionals have the supervision and control over the entire operation of the archaeological site of Mystras, including the Monastery (i.e. on the basis of a values-based approach).

places emphasis on the continual process of creation of a site by the core community, as an inherent obligation of the community to the site, and places protection within creation. A materialbased and a values-based approach mostly see heritage as a 'product', and treat any change in the fabric as something to be avoided, while a living heritage approach sees heritage as a process, considering change of the fabric as an inseparable part of this process. Thus, a living heritage approach accepts that, even if the physical, material structure of a site may be harmed, the authenticity of a site would not actually be harmed as long as the process of creation, in accordance with its original function, would continue. For a material-based and a values-based approach the past is mostly regarded as 'dead', and seeking authenticity is unattainable, while for a living heritage approach the past is part of the ongoing present, or rather there is only present (the boundaries between the past, the present and the future are eliminated), and authenticity can never be lost thanks to the continual process of the creation of a site. Thus, it could be argued that, according to a materialbased and a values-based approach, conservation professionals seek, and try to preserve, an 'aura' 
of authenticity (Lowenthal 1989, 846; Holtorf and Schadla-Hall 1999, 231; Cunha 1995, 262-263), whereas, according to a living heritage approach, the actual authenticity is continually defined by a site's core community everyday presence in, and creation of, a site. Therefore, a values-based approach tends to see and preserve a site as 'heritage', while a living heritage approach sees and enhances the further creation of a site as a 'living reality'.

The difference between the concepts of 'heritage' and 'living reality' may be shown in Buffy Saint-Marie's song '...now that my life is known as your heritage' (Saint-Marie 1966) and in Ndoro's words, with reference to Great Zimbabwe in Zimbabwe 'Your Monument Our Shrine' (Ndoro 2001). This difference is raised, with reference to Australia, as follows:

Archaeologists and others involved in the study of Aboriginal culture, past or present, should ask themselves what is more important, the preservation of a few relics of the recent past, or the active continuation of that living culture? (Bowdler 1988, 523).

\section{Shifting from preservation towards creation}

A living heritage approach suggests that the discipline of conservation does not simply attempt to expand within its current theoretical framework and practice (as defined by a values-based approach), but is substantially changed. Conservation should move towards a completely different context of understanding and safeguarding heritage: shifting the focus from preservation towards creation. Conservation needs to 'escape' from the discontinuity created between the monuments, considered to belong to the past, and the people of the present and also from the attachment to the fabric, and move towards the embracement of people's associations with sites and the continual process of creation of the sites in the context of these associations. The focus, therefore, should not be on how to limit the impact on the fabric for the sake of the preservation of the past, but on how to support, manage and guide the evolution of people's association with sites over time and into the future. The aim is to change the entire way heritage is perceived, protected and, more importantly, further created. 